\title{
The Everyday in Heidegger's Revolutionary Thought
}

\author{
NERIJUS STASIULIS \\ Department of Philosophy and Cultural Studies, Faculty of Creative Industries, Vilnius Gediminas Technical University, \\ 26 Pylimo/1 Trakų Street, Room 102, 00132 Vilnius, Lithuania \\ Email: nerijus.stasiulis@vgtu.lt
}

\begin{abstract}
The article emphasizes the primacy of the everyday in Heidegger's ecstatic thinking. It assumes the crucial link between practical and ontological aspects of Heideggerian phenomenology and thus also deals with the hermeneutic and political aspects of the Heideggerian stance. The latter is presented as inseparable from (post)modern revolutionary mood as his reconsidering of the concept of essence implies reconsidering the concept of revolution. Links between the meaning of the phenomenological terms of das Man, der Schein, etc. and the Greek thinking of essence are stressed. The Greek inspired phenomenological solution to the guiding practical and hermeneutic issue of our time - that of withdrawal of gods - is presented as the gist of Heideggerian thought.
\end{abstract}

Keywords: gods, Heidegger, presence, revolution, the everyday, the Greeks

\section{REVOLUTION AS ESSENCE: INTRO}

We shall discuss the relationship between the ontological structure of ek-sistence and of the Eigentlichkeit ${ }^{1}$ of the everyday in Heidegger's thought. To word the problem differently, how is eigentlich existence (and the everyday) possible? The how in this question indicates precisely the form, or the structure, that is, we shall deal with the most general mode of approach of such an existence as opposed to any possible concrete contents thereof. Our question is akin to the Kantian one on the how of the possibility of a priori synthetic judgments; hence what we shall discuss may be named the transcendental form of eigentlich practice as opposed to the content or concrete actions taking place therein.

1 We choose for the most part to preserve the German Heideggerian terms (in Italic) untranslated in order to avoid useless or misleading (for our purposes) connotations. We use the English the instead of the German der, die, das to mark nouns or nominalizations but we only use a capital as the first letter for German nouns while we start nominalizations with a minuscule. Note that 'man' in 'the man' $[\mathrm{m} \Lambda \mathrm{n}$ ] does not refer to 'human' or 'male' but to the German indefinite pronoun used by Heidegger to coin his well-known das Man.

The usual translation of das Man - the 'they', as the reader shall see furtheron, is unfit for our purposes. In this paper, we focus on interpretation rather than translation of key Heideggerian terms. And, for this reason, we shall also omit referring to the usual English translations to avoid unnecessary confusion. Where necessary, we introduce our own English version of a Heideggerian term. 
It shall be crucial to keep in mind that there is no gap to be bridged between theory and practice. They are inseparable as eidos (essence) and entity. Practice is 'content', while the concept of essence is 'form'. Historically, changes of the everyday have occurred alongside the changes of the concept of essence. Our current revolutionary mode of thinking and acting is also due to (our relation to) the concept of essence. In fact, essence and revolution are philosophically synonymous. All of this was well-surveyed by Gintautas Mažeikis (2017) who described the historical development of the concepts of revolution and essence and the corresponding changes in the development of the everyday (including the changes related to both revolutionary political activity and revolutionary mood of the everyday).

The ancient concept of essence is related to the 'cyclical', or 'revolutionary' (in Latin revolutio means returning, recurrence), notion of the world. For instance, Bergson understands the ancient notion of essence in terms of (eternal) past, as one denoting 'having always been' and thus deprived of novelty. As recounted by Mažeikis (ibid.), Roman Stoics, Marcus Aurelius and Seneca, used the everyday Latin saying 'revolta dies' ('day which has returned') to mean the principle of the return of days, of the eternal recurrence of the inevitable. Revolution here had the meaning of returning to the essence which has been, or the day which has been. This notion was passed on to the Middle Ages as well as on to the Renaissance as the notion of essential cycles (Copernican cosmology would serve an example). According to Mažeikis (ibid.), the concept of revolution has since undergone a historical inversion as revolution is now understood as an attempt to free from essential determination. Thus, currently the orientation of revolution is radically futural. Accordingly, the notion of radical has also undergone a historical inversion (ibid.) as its current revolutionary meaning of extremity is opposite to the original concept of root, rootedness.

Mažeikis (ibid.) indicates that the radical inversion of the concept of revolution (essence) occurs only around 1871. Early modern political thinkers such as Hobbes and Rousseau modelled their thinking according to the image of the essential natural condition of Man which was located in the past. The American revolution was still a returning to the natural (essential) order, whereas in France Robespierre still sought a return to the Roman Republic, and Napoleon to the Roman empire. Marquis de Sade, like Rousseau, wished a return to the natural essence. But the Paris Commune, emphasizes Mažeikis, was the first to talk about radical breaking out of previous cycles and not-returning. To note, we have observed here a modification of the concept of essence/revolution from one denoting eternal past to one dealing with temporal past and then with the one oriented towards breaking free from that past.

If Heidegger is right in his retrieval of the Greek conception of essence by (re)discovering the unity of the ek-stasies of past and future, gathered by the (ever) present, so we must admit that the Roman notion moved away from the original Greek concept in the direction of the inevitability of eternity and, as it were, of the detemporalization of the Greek concept, while in the modern concept of revolution we, on the contrary, find an extreme temporalization and historization of essence and, eventually, we end up with a separation of and contradiction between past and future. Revolution gets oriented toward the future. In 1921, continues Mažeikis, the revolt in Hallstatt understood revolution as breaking out of a certain environment. And, finally, only Bolshevik-like revolutions sought (futural) emergence toward the new essence. The revolution of the everyday in 1968, then, had to do with breaking out of any essence, or emerging beyond essence. Because to them essence referred to hegemonies which were integrated into our everydayness. But this purely futural emergence beyond essence through spontaneity has proved fruitless because 'capitalism' possesses a more powerful 
spontaneity of its own. Ideas of marketing have proven to be more powerful than spontaneous tactics of the consumer. Thus, says Mažeikis, post-everyday revolutions integrate 'essential' strategic thought to contribute to the tactics of spontaneity. Spontaneous (futural) individuality has been substituted with spontaneous networks that make use of contemporary (technology of) communication.

Hence, the form, or structure, upon which our everydayness hangs is that of revolution. According to the way Mažeikis describes it, the concept of essence has developed from being understood under the aspect of the past - at first as something that has been there eternally, then as what has already been and then as something emerging from or contrary to what has been - to being understood under the aspect of the future, which is setting itself free from and is contrary to the past. This is precisely what the current meaning of revolution upon which the sentiment and behaviour of the everyday hangs consists in.

Whereas in Heidegger ovoía (essence/revolution) is not understood in terms of either past or future or merely in terms of their contraposition. The true meaning of ovoi $\alpha$ for him (as it was already for the Greeks) contains the three ecstasies of time and its structure is the futural returning to the have-been, bound by the moment of the present, or - in later Heideggerian terms - Lichtung. The three ecstasies of time form a unity and they are a reading of the concept of ovoí (essence) which coincides with the concept of our everydayness.

We begin the article with the above excursus to indicate that the concept of revolution/ essence is fundamental to both Western thought and Western everyday practice(s). Accordingly, Heidegger's thinking also deals with the concept of essence/revolution which is naturally connected to his concepts of the everyday and the political, i.e. his Existential of the man. ${ }^{2}$

\section{THE PROBLEM: TOTALITARIANISM AS WITHDRAWAL OF GODS}

What is the structure of essence/revolution in Heideggerian thought and how is it embodied in the everyday?

Firstly, it is manifest as the man. But, in fact, the man is a mode of the fundamental and stable structure of the phenomenon and it is - to fix it phenomenologically - always the primarily manifested mode of the presence of an affair. ${ }^{3}$ Any being present, any given situation - be it liberal, democratic, national socialist, etc. - is the man and the primary presence of the phenomenon. The structure upon which the actual situation, the actual affair is based is accepted as a given - as manifestation of the phenomenon and thus of Providence - and Heidegger does what he, as a thinker, must, i.e. he performs the eigentlich movement of the proper pondering and absorbing of the situation by demonstrating/accepting its structure of ontological difference (cf. Sá 2014: 62).

Here it is also important to heed that the man - contrary to ample but mistaken presentations (cf. Safranski 1998: 226-229) of this crucial conception - does not essentially refer to the superficiality of ever expanding excess of knowledge and news characteristic of the time (even though one of the structural characteristics of the man - the Neugier - is possibly at its basis). The man could also be mistakenly linked exclusively to liberal tendencies in the Weimar Republic, just like the eigentlich existence could mistakenly be identified - as contrary and opposed

2 These et al. have touched on the issues addressed in this article: R. Aumiller (2017), S. Claxton (2017), K. Riemer, R. B. Johnston (2017), Ž. Svigaris (2017), T. Kačerauskas, T. Věželis (2016), T. Sodeika, R. Šerpytytė, D. Bacevičiūtė (2015), O. Demetriou (2016), O. Demetriou (2016), J. Kučinskas (2015), M. Holy-Luczaj (2015), N. Milerius (2013), A. Šliogeris (1985). 
to the uneigentlich - with the opposition that the 'helpless chatter' of the Weimar Republic met in the guise of National Socialism. This false identification of eigentlich existence with the National Socialist program could then be falsely ascribed to Heidegger. But that would be a barbaric interpretation of the Heideggerian stance.

To appreciate the true direction of this stance, we must again heed the subtle connection between the notions of Eigentlichkeit and revolution (essence). According to the thinker, the 'authentic' existence is not retracted from and does not neglect the inauthenticity of the man but stays with and absorbs it. Thus, it may seem, revolutionism is not characteristic of his thought; what is more, his philosophy and even his own self have at times been reprehended for conformism, utmost passivity or, plainly, for 'lack of character'. On the other hand, if we all inevitably hang on the manifestation of essence, or ovjoía, and both ovjoí $\alpha$ and revolution mean the same, then there can be no non-revolutionary stance; and the difference between 'revolutionism' and 'nonrevolutinism' is only due to the kind of interpretation of ov $\sigma i \alpha$ which each of them manifests. Our man, or presence, which the Dasein has been thrown into and has to absorb, is oúria (essence); in other words, revolution is the phenomenon upon the how of which we all hang. It is our Dasein. That is, what makes the difference is precisely our relation to revolution/ovoí $\alpha$, the way we approach it. In each case we deal with ousia and revolution but it is in each case understood differently and is therefore differently manifested. Heidegger's stance is fundamentally revolutionary.

The political stirs of the time were based upon the inertia of revolution and it is precisely (and 'merely') the difference of the Heideggerian conception of revolution that distinguishes him from the rest and, perhaps, even renders him a sober man among drunkards (cf. Aristotle: Met. 1.984b). His Denken revealed the eigentlich structure of revolution/essence as that of ontological difference and was therefore able to grasp the essence of totalitarianism to consist in the withdrawal of gods.

\section{THE SOLUTION: PRESENCE}

\section{THE EVERYDAY AS PRESENCE}

What is the structure of this eigentlich ek-sistence and the everyday?

For Heidegger, the everyday is phenomenon. The everydayness is precisely the primary place where we live or have our dwelling. It is characterized by the fourfold - it is the place where heaven, earth, gods and mortals meet. We need to underline right away that gods are here conceived phenomenologically - as revelation of Being; in Heidegger, gods, or Godhead, denote precisely the shining through of Being. His parlance on the fourfold is to be distinguished from the quarrel between polytheism and monotheism, (neo)paganism and Christianity, New/Old age discourse and the like. It is a matter of the structure of the phenomenon as the appearing, the shining as the ontological difference.

This phenomenon (Heidegger 2000: 158) manifests itself as, for instance, a dwelling-place where every day we happen to be at a house and a bridge, and the two are at different distances (farnesses or proximities) from each other and other things; this place (expanse, room) is the $d a$ where we orient. This primary distance between things can then be abstracted and be taken as pure distance (lat. spatium $\rightarrow$ space). This spatium can then be further abstracted when we turn the bridge or the house into pure markings to get pure measures - dimensions of length, width and depth. And this is no longer spatium but extensio (Descartes). Now this extended space can be further abstracted into a multiplicity of any number of dimensions 
one prefers. It is in this most abstract ((post-)Cartesian) space that we measure the directions of objects and calculate their mass. And, importantly, we take the latter space to be the true, essential and primary one. We can say that here the objective space has dethroned the everyday dwelling-place, or - here a revolution in the 'modern' sense has taken place. One even usually remarks (cf. Rimkus 2017) that the everyday common sense and the objective science are utterly at odds because the former is supposedly unable to grasp the more fundamental nature of the latter.

The objective space and objects therein then serve as a means for the futural revolutionary undermining of existing realities. It sets itself free from the past as the throwness into the everyday and the common sense of the real. Therefore, the man, or primary presence, is here no longer understood as Schein, i. e. the presencing of the phenomenon, but merely as a show (Erscheinung), as 'illusory' (cf. SZ: 29). The truth is then only available as object while its original, eigentlich, structure of the ontological difference is concealed. The shining, gods, as the mode of the everyday presencing of the $d a$, has withdrawn.

Obviously, the withdrawal of gods is only their reign concealed. Does it perhaps take the shape of the (futural) revolution? Shall we recognize the workings of Godhead in the time of the setting sun?

Where shall we look for a means for such a recognition? For Heidegger, the future as uncovering of Being is only possible as thrown. Therefore, the eigentlich of existence indicates that the scientifically unconcealed space and the everyday dwelling-place are not in opposition. Furthermore, the scientific space is derivative of the everyday. This stance is akin to the Greek one and, most obviously, to the Aristotelian thought where the outset of Western thought took place. This outset is characterized precisely by the absence of the contradiction between the everyday and the theoretic. To be precise, the Greek/Aristotelian thought has the phenomenal structure the description of which is the gist of Heidegger's (own) phenomenology.

\section{THE GREEK DASEIN AS PRESENCE}

Take heed that, according to Aristotle, every investigation should begin with or be grounded upon two things - $\varepsilon \mu \pi \varepsilon \imath \rho i \alpha(\varphi \alpha \iota v o ́ \mu \varepsilon v \alpha)$ and $\varepsilon^{\prime} v \delta o \xi \alpha$ (cf. EN 1145b2-7; EN 1154b3-8; Top. 100b21-23). Aristotle is not skeptical against the everyday (the senses or accepted views) and, indeed, the methodic doubt upon which the (post-)Cartesian space as well as the dethroning, or depresencing, of the everyday $d a$ is grounded is not incidental to his philosophy.

The $\varepsilon^{\prime} v \delta o \xi \alpha$ are the man (sagt). They refer to accepted, famous opinions or views and here we note the structural correspondence to the man. One must begin with and trust the man sagt. It is crucial to the Heideggerian notion of essence, or revolution, characterized by the unity of Entwurf and Geworfenheit. Accordingly, Aristotle addresses $\varphi \alpha \iota$ ó $\mu \varepsilon v \alpha$ by trusting the initial point of investigation to (wo)men who have gained experience in certain fields (experts in the original sense) in the course of their everyday practices. It is only because of this everyday unconcealment that we have access to the deeper theoretical one. To be precise, theory ('merely') points out the structure which has been there beforehand underlying the everyday as manifestation of this structure.

As we said, the underlying structure, or form, of our (Western) everyday is essence/revolution (ovoi $\alpha$ ). The subject-matter or the task of Heideggerian thought is the distinction between the eigentlich and uneigentlich revealing of this structure. So what, according to Heidegger, is the structure of the everyday for the Greeks? What is the structure of the Greek $d a$ ? What is the Greek Dasein? 
In theoretical/ontological terms, revolution/essense/ovoí gathers future and past into a unity by the Augenblick, or the present moment, or presence. Heidegger stresses this presentic conception: the Greek ov oi $\alpha$ means this presence, or isness. Presence, phenomenologically conceived, is, to use another word, a phenomenon, i. e. the what-is-manifest through what it is manifest (the Schein), but, in being thus manifest, it ever remains concealed as being manifested. The manifestation, the what-is-manifest has ever the latent side. It is only because of the latent that the manisfest is manifested: it is the Heideggerian unity of Eigentlichkeit and Schein where the former indicates the latent Being and the latter - the way it is manifested. Importantly, all Greek life, their Dasein and their theory - which encompasses and consists of all disagreements among separate philosophers as well as the eminent quarrel between the philosopher and the sophist - take place in the single 'space' of the above-described unconcealment, or presence.

Let us have a few examples.

In his comment on the stance of Protagoras manifested in the famous saying ( $\pi \dot{\alpha} v \tau \omega v$

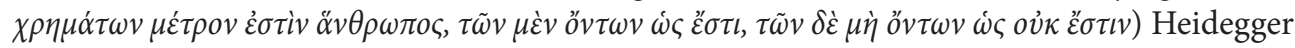

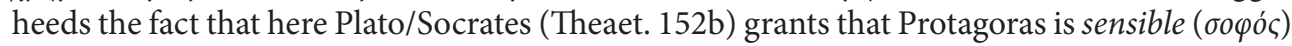
and his words are no nonsense. They are sensible in the sense that they grasp the phenomenal aspect of manifesting (Heidegger 1997: 135-141; cf. Heidegger 2006: 28-34). 'The way Protagoras defines the relation of people to beings is merely an emphatic narrowing of the unconcealment of beings to the vicinity of worldly experience which is each time one's own' (Heidegger 1997: 139) (Heidegger says this to distinguish Protagorian Dasein from the Cartesian Ego). The difference between the philosopher and the sophist is not that of contraposition or contradiction but rather consists in the fact that the philosopher performs a further move beyond the grasping of the Schein towards the very moment of its unconcealment, towards the very eigentlich of the phenomenon. The problem with the sophist is precisely (and merely) that they do not perform the move to deepen the very givenness of presence and hence they fail to appreciate the latent side.

Heidegger indicates the same structural moment in his discussion of the disagreement between Aristotle and Antiphon (Heidegger 1979: 266 and on), a famous thinker or sophist at the time. Antiphon, alongside Democritus, is one of the names which stand at the beginning of the line leading to the current physical ontology/imagery of fundamental particles as objects of science. According to the Greek notion, to be is to be present, presentic, and therefore, stable. The Antiphonian version thus has it that the underlying ov $\sigma i \alpha$ of things is a stable 'element' ('particle'). Aristotle disagrees because, according to him, the ov $\sigma i \alpha$, the underlying principle of isness is $\mu \rho \rho \varphi \eta$. Heidegger goes on to explicate the implicit understanding of $\mu о \rho \varphi \dot{\eta}$ as unconcealing, i.e. he shows $\mu о \rho \varphi \dot{\eta}$ to have the structure of the ontological difference. But, importantly, the disagreement between Aristotle and Antiphon is not 'radical' because of the more fundamental implicit agreement on Being as presence. The Greek Dasein merely needs proper 'handling. The failure of Antiphon is precisely the failure to grasp presence as unconcealment where Aristotle is a success, even though only implicitly.

\section{HORROR: REVOLUTION AS UN-CONCEALMENT}

Now, for Heidegger, the man is the Schein. The structure, discovered by Heidegger through his analysis of the Greek Dasein, is displayed in his consideration of the man. As phenomenal shining, the man should be accepted and its givenness should be transformed with the additional move of perceiving it as unconcealment, i.e. as revelation of latent Being. 
What is another description of this structure presented by Heidegger? The thinker indicates the paradoxical structure of this (Greek) shining when he brings to our attention the Greek $\varepsilon^{\prime} v \delta_{o} \xi_{0 v}$ ' $\lambda \dot{\alpha} \theta \varepsilon \beta \iota \dot{\varepsilon} \sigma \alpha \varsigma^{\prime}$. The saying does not suggest living in the hiding but rather $\lambda \alpha v \theta \dot{\alpha} v \omega$ refers to the state of constant concealment, of ever being latent (Heidegger 1992: 35-37). Here we see that the essence of shining, unconcealing has, paradoxically, to do with concealing. Shining is concealing. This is the model for the eigentlich existence.

To ask about the how of this paradoxical essencing is to ask about the how of the eigentlich existence. The question cannot be answered but it can be absolved. One can merely point to the necessary a priori condition of this absolving.

The condition is the fundamental mood of fright, or horror (Angst) which befalls us or is present to us in our relation to the man. Perhaps the everyday can be more appropriately described by boredom than by horror but boredom is but an extensive manifestation of what horror is an intensive one. As time dispersed into a sequence of present moments is rooted in boredom, so does ecstatic gathering of time presupposes horror.

Nothingness in the shape of horror can be manifest either 1) 'metaphysically', 'theoretically', or 2) 'practically'. In the first case it is revealed as givenness of pure nothing in an ordinary situation which poses no danger or threat whatsoever (this may have befallen Heidegger before 1933 as the sense of the primeval power of the night). In the second case it is revealed as calm powerlessness where danger is no longer uncovered by simple Furcht because it is beyond one's power to avoid it (such greatness of the terrible may have struck Heidegger after 1933). But the essence of the two is identical. It is about the revelation of nothing latent beneath the pure shining of the man. And as long as we do not come face to face with the nothing lurking beyond appearance we are not able to understand the appearing as phenomenon (unconcealing). Therefore, horror is the a priori conditio sine qua non for eigentlich ek-sistence.

What does it indicate in terms of Heideggerian 'non-revolutionary' stance? Or, more properly, what is the content of Heideggerian revolutionary stance in the sense of the aforementioned paradoxical givenness of ecstatic time? Should Heidegger have rebelled against national socialism instead of accepting its 'greatness of the terrible'? Had he rebelled, his action might have been 'praised' as revolutionary in the sense 'political'. But Heidegger's revolution has been directed ontologically.

If nationalsocialism (or liberaldemocracy, communism, etc. for that matter) was/is an instance of the man, then one was/is not in a position to 'escape' it. If horror is a fundamental ontological given latent beneath every appearing, then one is not justified in ascribing it merely to the Nazi or Communist concentration camps or the like because horror can become manifest in any situation whatsoever. It is part of the causal illusion that we can escape this fundamental condition, and this illusion is at the basis of what is currently called 'politics' and 'revolutionary' action. The true revolution as the gathering of ecstatic time necessarily involves remaining alongside the man and it is only by being prepared to accept its horror that we are able to do it. Only he to whom horror is revealed, who transforms the presence of Schein into the presence of phenomenon is enabled for and entitled to the eigentlich ek-sistence in the everyday.

\section{CONCLUSION: OUTRO}

So what is the Heideggerian stance in the time of revolution? It is not by considering his 'political preferences' or linking it to any definite content or political doctrine that we are able to appreciate its truth. It is about the phenomenological structure of thought. Was Heidegger lost in the stirs of his academic career, his psychological idiosyncrasies, in the difficulty and 
excitement of the historical situation, etc., was he drunken with an attempt to bring back Being by historico-political means? Or was he, aware of the ontological nature of the problem, the only sober man among many drunkards and did he make the eigeintlich move of the Augenblick which consisted in seeing the situation in ontological terms of the flight of gods and of the non-unconcealing of the Schein? Was it not evident to him that mere shining without presencing was at the root of the time of 'worldview', or 'ideology', which was/is not exclusively characteristic of nationalsocialism?

The political situation as ontological has the Being-historical side to it. We have not dealt solely with the phenomenological but also with the hermeneutical aspect of Heidegger's philosophy. Since the ontological situation has the historical aspect to it, the eigentlich phenomenological move turned hermeneutical in order to perform the unconcealing with respect to the man which was given to us a priori as our fundamental and guiding mode of relating to Being - the Greek concept. But this is to be discussed in full elsewhere (see Stasiulis 2017).

Again, Heideggerian thinking is not merely historical or temporal. It is ontological, i. e. the thinking of Being as shining. It says that any existing is firstly given as both uneigentlich and dangerous. Each situation requires the move of relating to it in an eigentlich fashion. The withdrawal of gods is merely a show. Presence is everywhere.

Received 1 March 2018

Accepted 15 June 2018

\section{References}

1. Aristotle. 1894. Aristotle's Ethica Nicomachea (Greek), ed. J. Bywater. Oxford: Clarendon Press. Available at: http://www.perseus.tufts.edu/hopper/text?doc=Perseus\%3atext\%3a1999.01.0053

2. Aristotle. 1924. Aristotle's Metaphysics (Greek), ed. W. D. Ross. Oxford: Clarendon Press. Available at: http://www.perseus.tufts.edu/hopper/text?doc=Perseus\%3atext\%3a1999.01.0051

3. Aristotle. 1995. "Topics", in The Complete Works of Aristotle, Volume 1: The Revised Oxford Translation, ed. J. Barnes. New Jersey, USA; West Sussex, UK: Princeton University Press.

4. Aumiller, R. 2017. "Dasein's Shadow and the Moment of Its Disappearance", Human Studies 40(1): $25-41$.

5. Claxton, S. 2017. Heidegger's Gods: an Ecofeminist Perspective. Rowman \& Littlefield International.

6. Demetriou, O. 2016. "Counter-Conduct and the Everyday: Anthropological Engagements with Philosophy”, Global Society 30(2): 218-237.

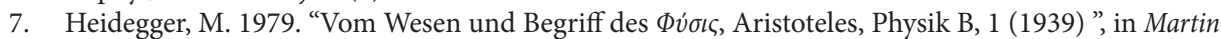
Heidegger. Gesamtausgabe. I. Abteilung: Veröffentlichte Schriften 1917-1970. Bd. 9: Wegmarken. Frankfurt am Mein: Vittorio Klostermann.

8. Heidegger, M. 1992. "Parmenides", in Martin Heidegger. Gesamtausgabe. II. Abteilung: Vorlesungen 19231944. Bd. 54: Parmenides. Frankfurt am Mein: Vittorio Klostermann.

9. Heidegger, M. 1997. "Der Europäische Nihilismus", in Martin Heidegger. Gesamtausgabe. I. Abteilung: Veröffentlichte Schriften 1910-1976. Bd. 6.2: Nietzsche. Frankfurt am Mein: Vittorio Klostermann.

10. Heidegger, M. 2000. "Bauen Wohnen Denken (1951)“, in Martin Heidegger. Gesamtausgabe. I. Abteilung: Veröffentlichte Schriften 1910-1976. Bd. 7. Vorträge und Aufsätze. Frankfurt am Mein: Vittorio Klostermann.

11. Heidegger, M. 2006. Sein und Zeit. Tübingen: Max Niemeyer Verlag.

12. Holy-Luczaj, M. 2015. "Heidegger's Support for Deep Ecology Reexamined Once Again: Ontological Egalitarianism, or Farewell to the Great Chain of Being", Ethics and the Environment 20(1): 45-66.

13. Kačerauskas, T.; Vežělis, T. 2016. Šiapusybès regionai: 50 Heideggerio filosofijos klausimų. Vilnius: Technika.

14. Kučinskas, J. 2015. „Kūrybingumas ir nihilizmas Arvydo Šliogerio filosofijoje: etinis ir ekologinis aspektai“, Filosofija. Sociologija 26(3): 210-219.

15. Mažeikis, M. 2017. Po-kasdienybés revoliucijos. Presentation in the Republican Conference „Kasdienybès vertybiniai aspektai: filosofijos, sociologijos ir komunikacijos perspektyvos" held by the Lithuanian Academy of Sciences, Vilnius Gediminas Technical University and Center for Social Research. Available at: https://www.youtube.com/watch?v=MphZOYg1LBM

16. Milerius, N. 2013. Apokalipsè kine: Filosofinés prielaidos. Vilnius: Vilnius University Press. 
17. Plato. 1903. Theaetetus. Plato. Platonis Opera, ed. J. Burnet. Oxford University Press. Available at: http:// www.perseus.tufts.edu/hopper/text?doc=Perseus\%3Atext\%3A1999.01.0171\%3Atext\%3DTheaet.\%3Asection $\% 3 \mathrm{D} 142 \mathrm{a}$

18. Riemer, K.; Johnston, R. B. 2017. "Clarifying Ontological Inseparability with Heidegger's Analysis of Equipment”, Mis Quaterly 41(4): 1059-1081.

19. Rimkus, E. 2017. Kasdienybe ir technomokslas. Presentation in the Republican Conference „Kasdienybès vertybiniai aspektai: filosofijos, sociologijos ir komunikacijos perspektyvos" held by the Lithuanian Academy of Sciences, Vilnius Gediminas Technical University and Center for Social Research. Available at: https://www.youtube.com/watch?v=lcMG6sv3_Ms\&t=3s

20. Sá, A. F. 2014. "Politics and Ontological Difference in Heidegger", in M. Heidegger. On Hegel's Philosophy of Right. The 1934-35 Seminar and Interpretive Essays. Transl. by A. J. Mitchell. New York: Bloomsbury.

21. Safranski, R. 1998. Martin Heidegger: Between Good and Evil. Transl. by E. Osers. London: Harvard University Press.

22. Sodeika, T.; Šerpytytė, R.; Bacevičiūtè, D. 2015. Ontologijos transformacijos: medijos, nihilizmas, etika. Vilnius: Vilniaus universiteto leidykla.

23. Stasiulis, N. 2014. Aristotelio filosofijos reikšmé Heideggerio mąstyme. Daktaro disertacija. Vilnius: Vilniaus universitetas.

24. Stasiulis, N. 2016. "On the Unity of Theory and Practice in Heidegger's Thought", Filosofija. Sociologija 27(3): 249-256.

25. Stasiulis, N. 2017. Egzistencialai kaip Aristotelio sqvoku raiška. Presentation in the Republican Conference „Egzistencializmas ir jo idejjų pédsakai XX a. kultūroje“ held by the Lithuanian Culture Research Institute. Available at: https://www.youtube.com/watch?v=AV5xPIt1Pq0\&t=539s

26. Svigaris, Ž. 2017. "The Recovery of Archaic Lithuanian Thinking: A Mythopoetic Worldview", Filosofija. Sociologija 28(1): 47-55.

27. Šliogeris, A. 1985. Žmogaus pasaulis ir egzistencinis mąstymas. Vilnius: Mintis.

\title{
Kasdienybė Heideggerio revoliuciniame mąstyme
}

\begin{abstract}
Santrauka
Straipsnyje pabrèžiamas kasdienybės pirmumas Heideggerio ekstatiniame mąstyme. Laikoma, kad lemiamą reikšmę turi sąsaja tarp praktinių ir ontologinių heidegeriškosios fenomenologijos aspektų, todèl aptariami Heideggerio laikysenos hermeneutinis ir politinis požiūriai. Šioji pristatoma kaip esanti neatskiriama nuo (post)moderniojo revoliucinio nusiteikimo, nes mąstytojo naujas esmès sąvokos apsvarstymas numano naują revoliucijos sąvokos apsvarstymą. Akcentuojamos sąsajos tarp fenomenologinių terminų das Man, der Schein ir kt., taip pat graikiškojo esmès mąstymo ir tų terminų reikšmès. Graiku įkvejptas fenomenologinis dabar aktualus praktinio ir hermeneutinio - dievų pasitraukimo - klausimo sprendimas pristatomas kaip heidegeriškojo mąstymo šerdis.
\end{abstract}

Raktažodžiai: dievai, graikai, Heideggeris, kasdienybè, prezencija, revoliucija 